\title{
Fibrin tissue adhesive versus nasal packing in endoscopic nasal surgery: a systematic review and meta-analysis*
}

James G. Coey, Paula J. Whittaker, Greg Williams, Umar H. Ikram, Oliver J. R. Page

Faculty of Biology, Medicine and Health, The University of Manchester, United Kingdom
Rhinology 57: 1, 21 - 31, 2019

https://doi.org/10.4193/Rhin18.112

*Received for publication:

May 26, 2018

Accepted: September 12, 2018

Background: It has been proposed that fibrin tissue adhesive (FTA) can act as an effective alternative to nasal packing in managing the postoperative symptoms of endoscopic nasal surgery.

Methodology: MEDLINE, Embase, Cochrane Library, The Cumulative Index to Nursing and Allied Health Literature and ClinicalTrials.gov were searched for randomised controlled trials comparing FTA with nasal packing in endoscopic nasal surgery. The primary outcome of interest was bleeding; secondary outcomes included pain, nasal obstruction, infection, adhesions and the formation of granulation tissue. All trials underwent a risk of bias assessment, and a meta-analysis was performed using a randomeffects model.

Results: 315 studies were found, of which four were eligible for inclusion $(n=152)$. Bleeding was reported in all, with the metaanalysis favouring the packing group, although this was not significant. Nasal obstruction and granulation severity were significantly lower in the FTA group, however, no difference was noted for the outcomes of pain, infection or adhesions.

Conclusion: Our results indicate minor advantages for using FTA over nasal packing. Unfortunately, the included studies show significant heterogeneity and risk of bias. Based on the available evidence, clinicians must balance the higher cost of FTA against the limited advantages for the patient.

Key words: epistaxis, fibrin tissue adhesives, nasal cavity, nasal surgical procedures, sinusitis

\section{Introduction}

\section{Rationale}

Nasal packing is often used as a method of controlling postoperative bleeding in various types of endonasal surgery, including functional endoscopic sinus surgery (FESS), septoplasty and conchotomy. Conventional packing materials such as Merocel are formed of a compressed, dehydrated sponge that is inserted into the nasal cavity at the conclusion of an operation; upon rehydration with blood, they expand to three times their normal size, compressing any bleeding vessels ${ }^{(1,2)}$. Despite their prevalence, the efficacy of these materials is often not substantiated by the evidence, with many studies reporting that endonasal procedures can be successfully managed without the use of nasal packing ${ }^{(3-5)}$. Furthermore, Merocel and other non-absorbable packs have been associated with increased pain and local infection whilst in situ, and significant pain upon removal ${ }^{(6-9)}$.

Attempts to rectify the drawbacks of Merocel have led to the development of absorbable nasal packs, such as Nasopore. These materials (formed of synthetic polyurethane foam) provide the initial structural properties required for haemostasis, alongside a hydrophilic component that allows their dissolution within a number of days ${ }^{(10)}$. One could reasonably expect that absorbable packs would be associated with less pain alongside a similar haemostatic efficacy, however the evidence is conflicting. One trial noted that Nasopore was a significant factor in the formation of excessive granulation tissue and major postoperative bleeding after FESS ${ }^{(11)}$, whilst a meta-analysis comparing Nasopore against Merocel concluded that the quality of evidence is too low to make any definitive conclusions ${ }^{(2)}$. Consequently, no 
method of managing the postoperative symptoms of endonasal surgery currently exists that isn't associated with additional risks for the patient.

More recently, biodegradable haemostatics have been suggested as a new material for managing the postoperative symptoms of endoscopic nasal surgery. Fibrin tissue adhesive (FTA) is a biodegradable solution containing concentrated fibrinogen, Factor XIII, thrombin and calcium; supplied in gel form it adheres strongly to tissue at the surgical site achieving instant haemostasis ${ }^{(12,13)}$. The topical application of FTA also negates the need for any postoperative removal, limiting the pain felt by patients ${ }^{(13)}$. If FTA was shown to be an effective haemostatic, it could theoretically replace the use of nasal packing and be associated with far fewer side-effects. Whilst debate surrounds the use of these materials regarding their expense, the adoption of FTA in other specialties, especially soft tissue head and neck surgery, is sufficient to warrant further investigation into its use in endoscopic nasal surgery ${ }^{(14)}$.

\section{Objectives}

To examine whether FTA is a safe and effective alternative to other methods of nasal packing in adult patients undergoing endoscopic nasal surgery. We reviewed randomised controlled trials (RCTs) that compared the use of FTA with absorbable or non-absorbable nasal packs and reported on the incidence of postoperative symptoms.

\section{Materials and methods}

\section{Protocol and registration}

This review was conducted in accordance with the PRISMA checklist ${ }^{(15)}$. The methodology of the review was determined in advance and registered on PROSPERO ${ }^{(16)}$.

\section{Information sources}

MEDLINE, Embase, The Cochrane Library, the Cumulative Index to Nursing and Allied Health Literature (CINAHL) and ClinicalTrials.gov were used to search for indexed articles to be included in this review. Searches were not limited by language or time of publication, and the last search was conducted on the 8th January 2018 (see Appendix 1-4 for full search strategy). Additional eligible studies were sought from the grey literature, the complete works of key authors and the reference lists of the included studies from the initial search.

\section{Eligibility criteria}

Only randomised controlled trials comparing the use of FTA with absorbable or non-absorbable nasal packing in adult $(\geq$ 18 years) participants undergoing endoscopic nasal surgery (FESS, septoplasty and conchotomy) were included. The primary outcome of interest was bleeding, with secondary outcome measures including postoperative pain, nasal obstruction, adhesion rate, infection rate and the formation of granulation tissue. This review was limited to the comparison of FTA with structural nasal packing (i.e. achieving haemostasis through compression), and so studies comparing FTA to other materials containing active haemostatic agents (such as thrombin in Floseal) were excluded ${ }^{(13)}$.

\section{Study selection and data extraction}

Study selection and data extraction were carried out according to the PRISMSA guidelines and completed independently by two reviewers (J.C and U.I); any disagreements were resolved by consensus through discussion with a third reviewer (PW) ${ }^{(15)}$.

\section{Risk of bias in individual studies}

Risk of bias was assessed independently by two authors (J.C and O.P) using the Cochrane Collaboration's tool for assessing risk of bias in randomised trials ${ }^{(17)}$. Each judgement was based on the guidance of adequate and inadequate methods of alleviating bias within each domain in the Cochrane Handbook ${ }^{(18)}$.

\section{Statistical analysis}

Cochrane $\mathrm{Q}$ and $\mathrm{I}^{2}$ tests were conducted to assess the studies included in the meta-analysis for heterogeneity ${ }^{(19)}$. The meta-analysis was performed by calculating effect sizes using a randomeffects model in order to have dichotomous and categorical outcomes in the same analysis ${ }^{(20)}$. The primary outcome for analysis was bleeding. For outcomes reported dichotomously, odds ratios were calculated and transformed into effect sizes using the formula $d=\operatorname{LnOR} \times(\sqrt{ } 3 / \pi)$ on Microsoft Excel ${ }^{(20)}$. For outcomes reported as means and standard deviations, Cohen's $d$ was calculated according to the formula $d=(M 2-M 1) /$ SDpooled $^{(21)}$. The effect size meta-analysis was conducted using Stats Direct statistical software version 2.8.0.

\section{Results}

Study selection

315 studies were retrieved from the search, of which six were eligible for inclusion. The PRISMA flowchart (Figure 1) details the number of studies at each stage of the selection process and the reasons for exclusion ${ }^{(15)}$. Unfortunately, upon initial analysis it became apparent that one study did not include a denominator in the results ${ }^{(22)}$, and a second study was noted to have a significant overlap in participants after consultation with the author ${ }^{(23)}$. These studies were subsequently removed, and the remaining four studies underwent analysis ${ }^{(12,24-26)}$.

\section{Study characteristics}

The study characteristics are presented in Table 1. The number of participants across all included studies was 152, with an average age of 40.4 years. All participants underwent FESS, with 88 of 


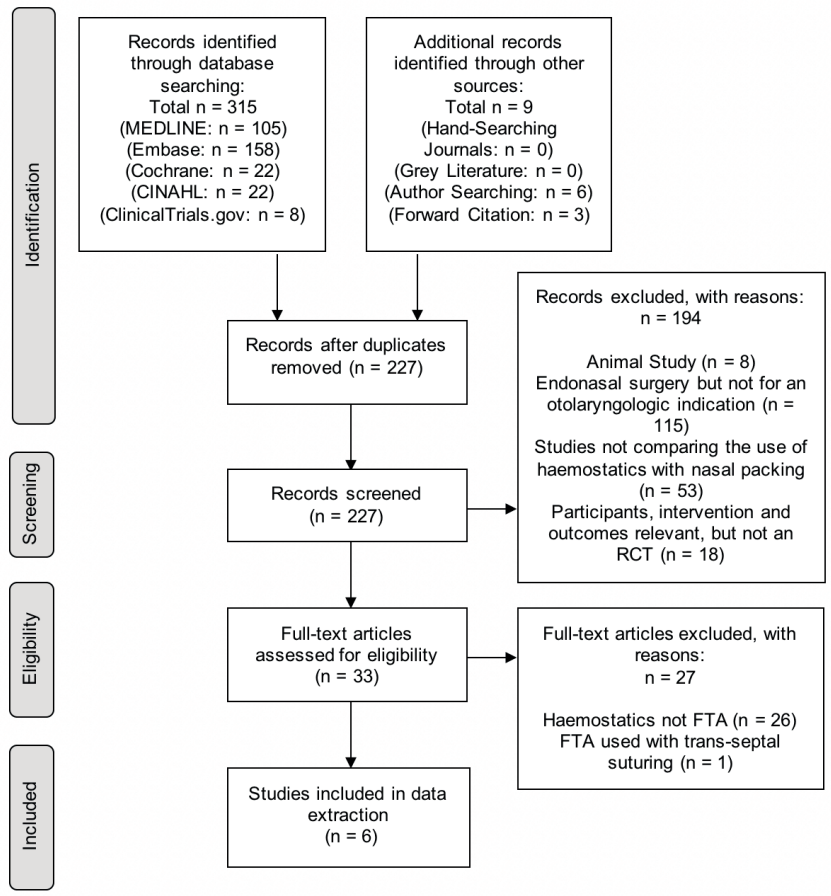

Figure 1. PRISMA flow diagram for the literature search ${ }^{(13)}$. RCT $=$ randomised controlled trial, FTA = fibrin tissue adhesive, $n=$ number of participants.

these acting as 'split-participants', meaning they received the intervention in one nasal cavity and the comparison in the other $(12,24,25)$. All studies used FTA as the sole intervention with either Merocel ${ }^{(12,26)}$, Nasopore ${ }^{(25)}$, or Gelfoam as the comparison ${ }^{(24)}$.

The outcomes were assessed by clinicians and/or participants. Bleeding, adhesions, infection rate and the formation of granulation tissue were clinician-assessed, and bleeding, pain and nasal obstruction were participant-assessed.

\section{Risk of bias within studies}

There was a significant level of variance in the quality of the included studies, with a frequently high risk of performance

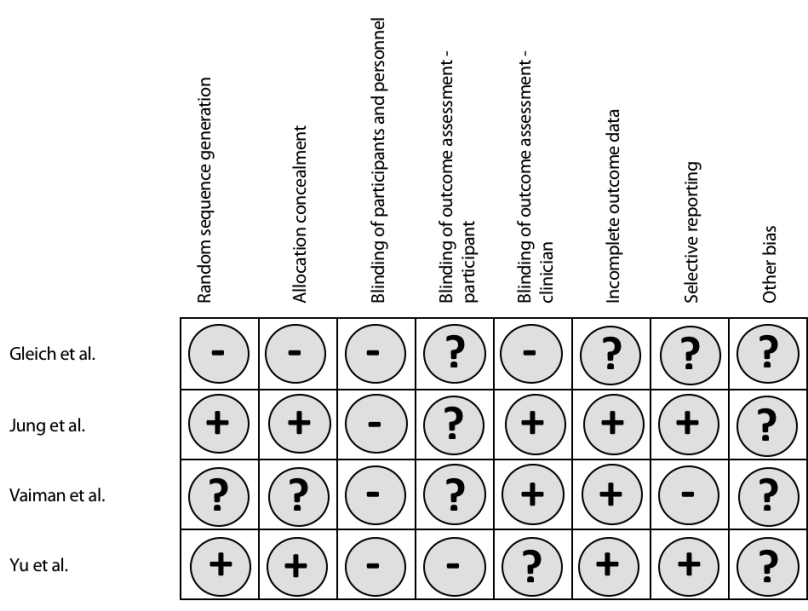

Figure 2. A summary of the Cochrane risk of bias assessment ${ }^{(16)}$. $+=$ low risk, $-=$ high risk, $?=$ unclear risk.

bias. This was likely due to the inability to blind patients to the intervention, as they would likely have been able to feel the nasal packing. Consequently, there was a reasonable degree of detection bias across all studies, as the participants acted as the assessors for certain outcomes and may have been influenced by knowledge of the intervention. The results of the assessment are summarised in Figure 2 and detailed for each included study in Appendix 5-8.

\section{Results of individual studies}

The results of the individual studies are detailed in Table 2. The studies by Vaiman et al. and Gleich et al. presented data as binary outcomes ${ }^{(24,26)}$; the studies by Jung et al. and Yu et al. used an ordinal scale ( $0=$ absent to $3=$ severe) to grade the severity of outcomes measured by clinicians, and a VAS ( $0=$ no symptoms to $10=$ unbearable) to grade the severity of outcomes measured by participants ${ }^{(12,25)}$. Since bleeding was assessed by both clinicians and participants in some studies, the method used is indicated in the table ${ }^{(12,25)}$. Additionally, where studies presented clinician-assessed outcome data on a range of follow

Table 1. Summary of study characteristics.

\begin{tabular}{|c|c|c|c|c|c|c|}
\hline Author & $\begin{array}{l}\text { n of participants } \\
\text { (mean age, } \\
\% \text { female) }\end{array}$ & $\begin{array}{l}\text { Operation } \\
\text { type }\end{array}$ & Follow up & $\begin{array}{l}\text { Inter- } \\
\text { vention }\end{array}$ & Comparison & Outcomes assessed \\
\hline Gleich et al. ${ }^{(25)}$ & $12(44.6,42 \%)$ & FESS & 3 months & FTA & Gelfoam & Bleeding, comfort, obstruction \\
\hline Jung et al. ${ }^{(24)}$ & $35(37.5,40 \%)$ & FESS & 12 weeks & FTA & Nasopore & $\begin{array}{l}\text { Bleeding, pain, obstruction, adhesion, } \\
\text { infection, granulation }\end{array}$ \\
\hline Vaiman et al. (26) & $64(35.6,47 \%)$ & FESS & 3 months & FTA & Merocel & Bleeding \\
\hline Yu et al. ${ }^{(12)}$ & $41(43.9,44 \%)$ & FESS & 12 weeks & FTA & Merocel & $\begin{array}{l}\text { Bleeding, pain, obstruction, adhesion, } \\
\text { infection, granulation }\end{array}$ \\
\hline
\end{tabular}

$\mathrm{n}=$ number, FESS $=$ Functional endoscopic sinus surgery, FTA = Fibrin tissue adhesive. 


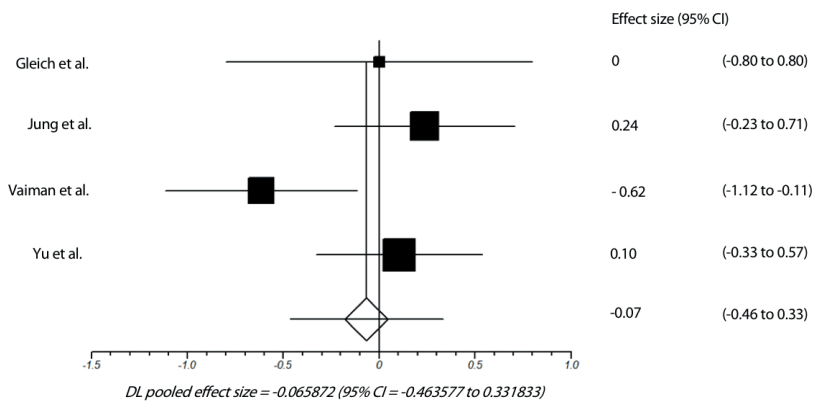

Figure 3. Forest plot for the primary outcome of bleeding $(6,7,22,25)$.

up times, bleeding data was extracted from the one-week postoperative results to maintain consistency with other studies and adhesion, granulation and infection data was extracted from the median follow-up time of four-weeks postoperative ${ }^{(12,25)}$.

\section{Syntheses of results}

A combination of limited reporting and/or flawed data across the studies for the secondary outcomes meant it was only appropriate to pool the results for the primary outcome of bleeding. Secondary outcomes have therefore been compared narratively.

\section{Primary outcome}

A random-effects model for meta-analysis was used following the results of the tests for heterogeneity, which showed a large difference between the included studies $\left(I^{2}=56 \%(0 \%\right.$ to $83.5 \%)$, $\mathrm{Q}=6.82, \mathrm{p}=0.08$ ). Figure 3 shows the forest plot of data for the four included studies ${ }^{(12,24-26)}$. The outcome of interest (lack of, or reduced severity of, bleeding) favoured the intervention in two of the included studies (Jung et al., $d=0.24(-0.23-0.71)$ and $\mathrm{Yu}$ et al., $d=0.10(-0.33-0.57))^{(12,25)}$, whilst one study showed no effect (Gleich et al., $d=0((n / a)-0.80))^{(24)}$, and the other study favoured the control over the intervention (Vaiman et al., $d=-0.62$ $(-1.12--0.12))^{(26)}$. The overall pooled effect favoured the control over the intervention $(d=0.10(-0.33-0.57))$ but this was not statistically significant $(p=0.75)$. Overall this meta-analysis must be interpreted with caution due to the high heterogeneity.

\section{Secondary outcomes}

Postoperative pain was reported in two studies ${ }^{(12,25)}$. No significant difference was reported in either study for 'pain during packing' or 'pain on dressing' between the FTA and control groups; a significant difference was however noted for'pain on packing removal' in one study ${ }^{(12)}$. Unfortunately, much of the data presented here is flawed: pain during packing was not clarified as the process of packing or the pain felt whilst in situ, and those in the FTA group did not receive packing and were therefore not applicable for inclusion in outcomes relating to packing removal. This also explains why the $p$-value was accordingly small $(p<0.0001)$ for the 'pain on packing removal' outcome ${ }^{(12)}$. Therefore, pooling of the results was not justified, and there is insufficient evidence to suggest that perceived pain is lower in

Table 2. Results of individual studies.

\begin{tabular}{|c|c|c|c|c|}
\hline Author & Outcomes measured & Results (Intervention) & $\begin{array}{c}\text { Results (Comparison) } \\
x / x=\text { frequency of event } \\
x \pm x=\text { mean score } \pm \text { SD }\end{array}$ & $\begin{array}{l}\text { Statistical } \\
\text { Significance }\end{array}$ \\
\hline Gleich et al. ${ }^{(25)}$ & $\begin{array}{l}\text { Nasal obstruction } \\
\text { Bleeding }\end{array}$ & $\begin{array}{l}\text { All reported FTA side felt more patent } \\
\qquad 0 / 12\end{array}$ & $\begin{array}{l}\text { See intervention column } \\
0 / 12\end{array}$ & $\begin{array}{l}\mathrm{ng} \\
\mathrm{ng}\end{array}$ \\
\hline Jung et al. (24) & $\begin{array}{l}\text { Bleeding* }(\mathrm{ca}) \\
\text { Bleeding (pa) } \\
\text { Pain during packing } \\
\text { Pain on dressing } \\
\text { Nasal obstruction } \\
\text { Adhesions** } \\
\text { Infection }^{* *} \\
\text { Granulation** }\end{array}$ & $\begin{array}{c}0.32 \pm 0.27 \\
6.1 \pm 2.8 \\
4.8 \pm 2.2 \\
5.1 \pm 2.3 \\
3.5 \pm 1.8 \\
0.58 \pm 0.63 \\
0.24 \pm 0.33 \\
0.41 \pm 0.40\end{array}$ & $\begin{array}{c}0.39 \pm 0.31 \\
5.2 \pm 1.3 \\
5.2 \pm 2.8 \\
5.9 \pm 2.7 \\
5.2 \pm 1.5 \\
0.48 \pm 0.38 \\
0.34 \pm 0.45 \\
1.24 \pm 0.61\end{array}$ & $\begin{array}{l}\text { NS } \\
\text { NS } \\
N S \\
N S \\
P<0.05 \\
N S \\
N S \\
P<0.05\end{array}$ \\
\hline Vaiman et al. ${ }^{(26)}$ & $\begin{array}{l}\text { Late bleeding ( } 48 \text { hours } \\
\text { after operation)c }\end{array}$ & $1 / 32$ & $0 / 32$ & $\mathrm{ng}$ \\
\hline Yu et al. ${ }^{(12)}$ & $\begin{array}{l}\text { Bleeding* (ca) } \\
\text { Bleeding (pa) } \\
\text { Pain during packin } \\
\text { Pain on removal } \\
\text { Nasal obstruction } \\
\text { Adhesions** } \\
\text { Infection** }\end{array}$ & $\begin{array}{c}0.34 \pm 0.47 \\
5.3 \pm 1.1 \\
4.2 \pm 1.4 \\
3.1 \pm 0.9 \\
7.5 \pm 1.2 \\
0.61 \pm 0.73 \\
0.24 \pm 0.53\end{array}$ & $\begin{array}{c}0.39 \pm 0.49 \\
5.8 \pm 1.3 \\
4.5 \pm 1.0 \\
8.1 \pm 1.1 \\
8.1 \pm 1.2 \\
0.49 \pm 0.52 \\
0.29 \pm 0.55\end{array}$ & $\begin{array}{c}\text { NS } \\
N S \\
N S \\
P<0.0001 \\
P=0.026 \\
\text { NS } \\
\text { NS }\end{array}$ \\
\hline
\end{tabular}

$\mathrm{ca}=$ clinician-assessed; $\mathrm{pa}=$ participant-assessed; NS = not significant; $\mathrm{ng}=$ not given, $\mathrm{n} / \mathrm{a}=$ not applicable, $\mathrm{SD}=$ standard deviation

${ }^{*}=1$-week postoperative results; ${ }^{* *}=4$-week postoperative results. 
participants receiving FTA.

Nasal obstruction was reported by three studies ${ }^{(12,24,25)}$. Obstruction was reported as significantly lower in the FTA group than the control in the studies by Jung et al. and Yu et al. who used VASs $(p<0.05(3.5 \pm 1.8$ and $5.2 \pm 1.5)$ and $p=0.026(7.5 \pm$ 1.2 and $8.1 \pm 1.2)$, respectively) ${ }^{(12,25)}$. Gleich et al. also reported a difference, however, this was a narrative description stating that all patient felt the FTA side felt more patent than the control side, with no provision of any raw data or statistical analysis to support this ${ }^{(24)}$.

The severity of adhesions was reported by Jung et al. and Yu et al., both of which noted no statistically significant differences between the FTA and control groups ( $p>0.05(0.58 \pm 0.63$ and $0.48 \pm 0.38)$ and $p>0.05(0.61 \pm 0.73$ and $0.49 \pm 0.52)$ respectively) ${ }^{(12,25)}$. In addition, there was also no significant difference noted for any other reported follow up time ${ }^{(12,25)}$.

The severity of infection was reported by Jung et al. and Yu et al., both of which again noted no statistically significant difference between the FTA and control groups ( $p>0.05(0.24 \pm 0.33$ and $0.34 \pm 0.45)$ and $p>0.05(0.24 \pm 0.53$ and $0.29 \pm 0.55)$, respectively) ${ }^{(12,25)}$. In addition, there was also no significant difference noted between the groups for any other reported follow up time ${ }^{(12,25)}$

The formation of granulation tissue was reported only by Jung et al., who noted that granulation was significantly lower in the FTA group compared to the control at postoperative week four $(p<0.05(0.41 \pm 0.40 \text { and } 1.24 \pm 0.61))^{(25)}$. No other reported follow up times noted a statistically significant difference between the groups ${ }^{(25)}$.

\section{Discussion}

\section{Quality of evidence}

The limitations of the included studies are important in understanding the applicability of these results. Although bleeding was a reported outcome in all studies, the small sample size coupled with a substantial risk of bias mean these results must be interpreted with caution. This is further enhanced by the exclusion of two eligible studies for poor outcome reporting and a $30 \%$ overlap in patients; this not only resulted in the loss of 698 participants from the analysis, but also the only data reporting on outcomes in septoplasty and conchotomy. Consequently, our findings are only applicable to FESS, and there was significant heterogeneity in the methodology of the remaining studies.

Unfortunately, the presence of only four eligible studies meant our original intention of performing a subgroup analysis for different packing materials was inappropriate. As a result, both absorbable and non-absorbable packing materials were grouped together, and the conclusions reached in this review cannot be used to differentiate between these materials.

\section{Comparison with other research}

A previous systematic review comparing all biodegradable materials to conventional nasal packing echoed the results of this review ${ }^{(13)}$. They too found no difference between the groups in postoperative bleeding rates and significantly less nasal obstruction in the biodegradable packing group ${ }^{(13)}$. Similarly, Yan et al. were unable to draw conclusions on individual materials (notably FTA) as a consequence of collating the results of all biodegradable haemostatics into one group ${ }^{(13)}$.

With advancing and meticulous surgical technique, immediate postoperative bleeding may be controlled without the need for nasal packing at all. Some studies have shown no difference in bleeding, adhesions, infection and nasal obstruction between using and omitting packing (both absorbable and non-absorbable) altogether in endonasal surgery ${ }^{(9,27)}$. Unfortunately, as has become a common theme, the existence of studies demonstrating evidence to the contrary (i.e. significant bleeding when packing is not used) confirms that decisions taken by clinicians continue to be based on personal preference ${ }^{(28)}$.

\section{Implications for clinical practice and further research} It is clear from the presented data that the current evidencebase is not yet robust enough to recommend the use of FTA in replacement of nasal packing. The lack of any cost-benefit analyses in the included studies also enhances concerns surrounding the expense of biodegradable haemostatics. Currently, the list price for $10 \mathrm{ml}$ of Artiss (a commonly used FTA) is $\$ 880.68$ (around $£ 680$ ) (29); this highlights the cost-effectiveness of Merocel, which can be bought for just $£ 2.61$ per pack ${ }^{(30)}$. Whilst savings made through shorter operation times or reduced follow-up visits might bring the cost of FTA more in line with that of nasal packing, commenting on this before a comprehensive cost-benefit analysis is performed would be inappropriate.

Despite these uninspiring results, they do serve to emphasise the lack of any comprehensive research in this area. Only when a multi-centre RCT compares the use of FTA with all forms of packing will clinicians be able to make a more informed choice about the material they recommend for their patients.

\section{Conclusion}

With many clinicians considering the management of postoperative symptoms in endoscopic nasal surgery just as important as the operation itself, it is surprising that there remains a significant disparity between the methods employed by different surgeons. Our preliminary results indicate advantages for using 
FTA over structural nasal packing with regard to nasal obstruction and the formation of granulation tissue, with no difference noted with respect to bleeding, pain, infection and adhesions. Whilst an interesting development, the current research is conducted on a small sample size and shows significant heterogeneity and performance bias. As such, drawing any meaningful conclusions is limited. Our results therefore serve to highlight the lack of research in this area, and should not be used to guide practice until clinical trials with more robust methodology are conducted.

\section{Acknowledgements}

With special thanks to Mr Sean Loughran (BSC Hons, MBBs Hons, FRCS) for revising the review.

\section{Authorship contribution}

JGC: designed the study, conducted the search, extracted the data on each study, performed the risk of bias assessment and wrote the review. PJW: contributed to the design of the study, reviewed the search and data extraction and wrote sections of the review. GW: contributed to the design of the study, performed the statistical analysis on the extracted data and wrote sections of the review. UHI: contributed to the design of the study, reviewed the search and reviewed the data extraction. OJRP: contributed to the design of the study, reviewed the data extraction and reviewed the risk of bias assessment.

\section{Conflict of interest}

No conflict of interest exists.

\section{References}

1. Pringle $M$, Beasley P, Brightwell AP. The use of Merocel nasal packs in the treatment of epistaxis. J Laryngol Otol. 1996; 110(6): 543-6.

2. Wang J, Cai C, Wang S. Merocel versus Nasopore for nasal packing: a metaanalysis of randomized controlled trials. PLoS One. 2014; 9(4). doi: 10.1371/journal. pone.0093959.

3. Eliashar R, Gross M, Wohlgelernter J, Sichel JY. Packing in endoscopic sinus surgery: is it really required? Otolaryngol Head Neck Surg. 2006; 134(2): 276-9.

4. Orlandi R, Lanza DC. Is nasal packing necessary following endoscopic sinus surgery? Laryngoscope. 2004; 114(9): 1541-4

5. Basha S, Gupta D, Kaluskar SK. Routine nasa packing follwoing nasal surgery-ls it necessary? Indian J Otolaryngol Head Neck Surg. 2005; 57(1): 69-71.

6. Bresnihan M, Mehigan B, Curran A. An evaluation of Merocel and Series 5000 nasal packs in patients following nasal surgery: a prospective randomised trial. Clin Otolaryngol. 2007; 32(5): 352-5.

7. Ardehali M, Bastaninejad S. Use of nasal packs and intranasal septal splints following septoplasty. Int J Oral Maxillofac Surg. 2009; 38(10): 1022-4

8. Tai C, Chu CC, Liang SC, et al. Use of patient satisfaction data in a continuous quality improvement program for endoscopic sinus surgery. Otolaryngol Head Neck Surg. 2003; 129(3): 210-6

9. Awan M, lqbal M. Nasal packing after septoplasty: A randomized comparison of packing. Ear Nose Throat J. 2008; 87(11): 624-7.

10. Yilmaz M, Guven M, Elicora SS, Kaymaz R. An evaluation of biodegradable synthetic polyurethane foam in patients following septoplasty: a prospective randomized trial. Otolaryngol Head Neck Surg. 2013; 148(1): 140-4.

11. Wang $Y$, Wang MC, Chen YC, Leu YS, Lin HC, Lee KS. The effects of Vaseline gauze strip, Merocel, and Nasopore on the formation of synechiae and excessive granulation tissue in the middle meatus and the incidence of major postoperative bleeding after endoscopic sinus surgery. J Chin Med Assoc. 2011; 74(1): 16-21.

12. Yu M, Kang SH, Kim BH, Lim DJ. Effect of aerosolized fibrin sealant on hemostasis and wound healing after endoscopic sinus surgery: a prospective randomized study. Am J Rhinol Allergy. 2014; 28(4): 335-40.

13. Yan M, Zheng D, Li Y, Zheng Q, Chen J, Yang B. Biodegradable nasal packings for endoscopic sinonasal surgery: a systematic review and meta-analysis. PloS one. 2014 9(12). doi: 10.1371/journal.pone.0115458.

14. Bajwa M, Tudur-Smith C, Shaw RJ, Schache AG. Fibrin sealants in soft tissue surgery of the head and neck: A systematic review and meta-analysis of randomised controlled trials. Clin Otolaryngol. 2017; 42(6): 1141-52.

15. Moher D, Liberati A, Tetzlaff J, Altman DG, Prisma Group. Preferred reporting items for systematic reviews and meta-analyses: the PRISMA statement. PLoS Med. 2009; 6(7). doi: 10.1371/journal.pmed.1000097.

16. PROSPERO International prospective register of systematic reviews. Fibrin tissue adhesives versus nasal packing in the treatment of patients undergoing endoscopic nasal surgery: a systematic review (January 2018) http://www.crd.york.ac.uk/PROSPERO/display_record.php?ID=CRD42018087776 April 5, 2018.

17. Higgins J, Altman DG, Gøtzsche PC, et al. The Cochrane Collaboration's tool for assessing risk of bias in randomised trials. BMJ. 2011; 343. doi: 10.1136./bmj.d5928.

18. Higgins J, Green S. Cochrane handbook for systematic reviews of interventions. UK: The Cochrane Collaboration, 2011.

19. Higgins J, Thompson SG, Deeks JJ, Altman DG. Measuring inconsistency in meta-analyses. BMJ. 2003; 327(7414): 557.

20. Chinn S. A simple method for converting an odds ratio to effect size for use in metaanalysis. Stat Med. 2000; 19(22): 3127-31.

21. Cohen J. Statistical Power Analysis for the
Behavioral Sciences. 2nd ed. Hillsdale, NJ: Lawrence Earlbaum Associates, 1988.

22. Vaiman M, Eviatar E, Segal S. The use of fibrin glue as hemostatic in endonasal operations: a prospective, randomized study. Rhinology. 2002; 40(4): 185-8.

23. Vaiman M, Sarfaty S, Shlamkovich N, Segal S, Eviatar E. Fibrin sealant: alternative to nasal packing in endonasal operations. A prospective randomized study. Isr Med Assoc J. 2005a; 7(9): 571

24. Gleich L, Rebeiz EE, Pankratov MM, Shapshay SM. Autologous fibrin tissue adhesive in endoscopic sinus surgery. Otolaryngol Head Neck Surg. 1995; 112(2): 238-41.

25. Jung M, Choi CH, Yu MS. Comparison of the effect of aerosolized fibrin sealant and biodegradable synthetic polyurethane foam on hemostasis and wound healing after endoscopic sinus surgery: a prospective randomized study. Int Forum Allergy Rhinol. 2017; 7(11): 1089-94.

26. Vaiman M, Shlamkovich N, Eviatar E, Segal S. Use of fibrin glue as a hemostatic in endoscopic sinus surgery. Ann Otol Rhinol Larngol. 2005b; 114(3): 237-41.

27. Wee J, Lee CH, Rhee CS, Kim JW Comparison between Gelfoam packing and no packing after endoscopic sinus surgery in the same patients. Eur Arch Otorhinolaryngol. 2012; 269(3): 897-903.

28. Mo J, Han DH, Shin HW, et al. No packing versus packing after endoscopic sinus surgery: pursuit of patients' comfort after surgery. Am J Rhinol. 2008; 22(5): 525-8.

29. Yamamoto KT, DeJoseph LM. Efficacy and Safety of Artiss Fibrin Tissue Sealant Use in Rhytidectomy: A Review of 120 Cases. Surg J. 2017; 3(2): 69

30. Badran K, Malik TH, Belloso A, Timms MS Randomized controlled trial comparing Merocel and RapidRhino packing in the management of anterior epistaxis. Clin Otolaryngol. 2005; 30(4): 333-7. 


\author{
James G. Coey \\ Stopford Building \\ Faculty of Medical and Human \\ Sciences \\ The University of Manchester \\ Oxford Road \\ Manchester \\ M13 9PT United Kingdom \\ Tel: +44 - 161 - 2755584 \\ E-mail: james.coey@doctors.org.uk
}

Appendix 1. Search Strategy for Medline (Ovid host).

\begin{tabular}{|c|c|c|}
\hline Search Term & $\begin{array}{l}\text { Thesaurus } \\
\text { Term }\end{array}$ & $\begin{array}{l}\text { Subheading / } \\
\text { Search Field }\end{array}$ \\
\hline 1. Nasal Cavity & $\mathrm{MeSH}$ & su \\
\hline 2. Paranasal Sinuses & $\mathrm{MeSH}$ & su \\
\hline 3. Sinusitis & $\mathrm{MeSH}$ & su \\
\hline 4. Nose & $\mathrm{MeSH}$ & pa, su \\
\hline 5. Endoscopy & $\mathrm{MeSH}$ & All Subheadings \\
\hline 6. Sinus $\$ 4$ adj4 Surgery & Free Text & $a b, h w, k f, t i, t w$ \\
\hline 7. 1 or 2 or 3 or 4 or 5 or 6 & Combination & $\mathrm{N} / \mathrm{A}$ \\
\hline 8. Fibrin Tissue Adhesives & $\mathrm{MeSH}$ & $\mathrm{ad}, \mathrm{ch}, \mathrm{pd}, \mathrm{tu}$ \\
\hline 9. Hemostatics & $\mathrm{MeSH}$ & $\mathrm{ad}, \mathrm{ch}, \mathrm{pd}, \mathrm{tu}$ \\
\hline 10. Tissue adj4 Adhesive\$ & Free Text & $a b, h w, k f, t i, t w$ \\
\hline 11. Fibrin adj4 Glue & Free Text & $a b, h w, k f, t i, t w$ \\
\hline 12. Fibrin adj4 Seal\#nt & Free Text & $\mathrm{ab}, \mathrm{hw}, \mathrm{kf}, \mathrm{ti}, \mathrm{tw}$ \\
\hline 13. Hemostasis & $\mathrm{MeSH}$ & de \\
\hline 14.8 or 9 or 10 or 11 or 12 or 13 & Combination & $\mathrm{N} / \mathrm{A}$ \\
\hline 15. Postoperative Haemorrhage & $\mathrm{MeSH}$ & $\mathrm{dt}, \mathrm{pc}, \mathrm{su}, \mathrm{th}$ \\
\hline 16. Postoperative Complications & $\mathrm{MeSH}$ & $\mathrm{dt}, \mathrm{pc}, \mathrm{su}, \mathrm{th}$ \\
\hline 17. Pain, Postoperative & $\mathrm{MeSH}$ & $\mathrm{dt}, \mathrm{pc}, \mathrm{su}, \mathrm{th}$ \\
\hline 18. Wound Healing & $\mathrm{MeSH}$ & de \\
\hline 19. Nasal adj4 Pack\$3 & Free Text & $\mathrm{ab}, \mathrm{hw}, \mathrm{kf}, \mathrm{ti}, \mathrm{tw}$ \\
\hline 20.15 or 16 or 17 or 18 or 19 & Combination & $\mathrm{N} / \mathrm{A}$ \\
\hline 21.7 and 14 and 20 & Combination & $\mathrm{N} / \mathrm{A}$ \\
\hline
\end{tabular}

$\mathrm{su}=$ surgery, $\mathrm{pa}=$ pathology, $\mathrm{ab}=$ abstract, $\mathrm{hw}=$ subject heading word, $\mathrm{kf}=$ keyword heading word, $\mathrm{ti}=$ title, $\mathrm{tw}=$ text word, $\mathrm{ad}=$ administration $\&$ dosage, $\mathrm{ch}=$ chemistry, $\mathrm{pd}=$ pharmacology, $\mathrm{tu}=$ therapeutic use, $\mathrm{de}=$ drug effects, $d t=$ drug therapy, $\mathrm{N} / \mathrm{A}=$ not applicable.
Appendix 2. Search Strategy for Embase (Ovid host).

\begin{tabular}{|c|c|c|}
\hline Search Term & $\begin{array}{l}\text { Thesaurus } \\
\text { Term }\end{array}$ & $\begin{array}{l}\text { Subheading / } \\
\text { Search Field }\end{array}$ \\
\hline 1. Nose Cavity & Emtree & su \\
\hline 2. Paranasal Sinus & Emtree & su \\
\hline 3. Sinusitis & Emtree & su \\
\hline 4. Nose & Emtree & pa, su \\
\hline 5. Endoscopy & Emtree & All Subheadings \\
\hline 6. Sinus $\$ 4$ adj4 Surgery & Free Text & $a b, h w, k w, t i, t w$ \\
\hline 7. 1 or 2 or 3 or 4 or 5 or 6 & Combination & N/A \\
\hline 8. Fibrin Glue & Emtree & $\begin{array}{l}\mathrm{ct}, \mathrm{ad}, \mathrm{dt}, \mathrm{na}, \\
\mathrm{pd}, \mathrm{tp}\end{array}$ \\
\hline 9. Hemostatic Agent & Emtree & $\begin{array}{l}\mathrm{ct}, \mathrm{ad}, \mathrm{dt}, \mathrm{na}, \\
\mathrm{pd}, \mathrm{tp}\end{array}$ \\
\hline 10. Tissue adj4 Adhesive\$ & Free Text & $\mathrm{ab}, \mathrm{hw}, \mathrm{kw}, \mathrm{ti}, \mathrm{tw}$ \\
\hline 11. Fibrin adj4 Glue & Free Text & $a b, h w, k w, t i, t w$ \\
\hline 12. Fibrin adj4 Seal\#nt & Free Text & $a b, h w, k w, t i, t w$ \\
\hline 13. Hemostasis & Emtree & All Subheadings \\
\hline 14.8 or 9 or 10 or 11 or 12 or 13 & Combination & $\mathrm{N} / \mathrm{A}$ \\
\hline 15. Postoperative Haemorrhage & Emtree & $\mathrm{co}, \mathrm{dt}, \mathrm{pc}, \mathrm{su}, \mathrm{th}$ \\
\hline 16. Postoperative Complications & Emtree & $\mathrm{co}, \mathrm{dt}, \mathrm{pc}, \mathrm{su}, \mathrm{th}$ \\
\hline 17. Pain, Postoperative & Emtree & $c o, d t, p c, s u, t h$ \\
\hline 18. Wound Healing & Emtree & $\mathrm{dt}$, th \\
\hline 19. Nasal adj4 Pack\$3 & Free Text & $a b, h w, k w, t i, t w$ \\
\hline 20.15 or 16 or 17 or 18 or 19 & Combination & $\mathrm{N} / \mathrm{A}$ \\
\hline 21.7 and 14 and 20 & Combination & $\mathrm{N} / \mathrm{A}$ \\
\hline
\end{tabular}

$\mathrm{su}=$ surgery, $\mathrm{pa}=$ pathology, $\mathrm{ab}=\mathrm{abstract}, \mathrm{hw}=$ heading word, $\mathrm{kw}=$ keyword, $\mathrm{ti}=$ title, $\mathrm{tw}=$ text word, $\mathrm{ct}=$ clinical trial, ad = drug administration, $\mathrm{dt}=$ drug therapy, na = intranasal drug administration, $\mathrm{pd}=$ pharmacology, $\mathrm{tp}=$ topical drug administration, $\mathrm{co}=$ complication, $\mathrm{pc}=$ prevention th $=$ therapy, N/A = not applicable. 
Appendix 3. Search Strategy for The Cochrane Library.

\begin{tabular}{|c|c|c|}
\hline Search Term & $\begin{array}{l}\text { Thesaurus } \\
\text { Term }\end{array}$ & $\begin{array}{l}\text { Subheading / } \\
\text { Search Field }\end{array}$ \\
\hline 1. Nasal Cavity & $\mathrm{MeSH}$ & su \\
\hline 2. Paranasal Sinuses & $\mathrm{MeSH}$ & su \\
\hline 3. Sinusitis & $\mathrm{MeSH}$ & su \\
\hline 4. Nose & $\mathrm{MeSH}$ & pa, su \\
\hline 5. Endoscopy & $\mathrm{MeSH}$ & All Subheadings \\
\hline 6. Sinus Surgery & Free Text & $\mathrm{ab}, \mathrm{kw}, \mathrm{ti}$ \\
\hline 7. 1 or 2 or 3 or 4 or 5 or 6 & Combination & $\mathrm{N} / \mathrm{A}$ \\
\hline 8. Fibrin Tissue Adhesives & $\mathrm{MeSH}$ & $\mathrm{ad}, \mathrm{ch}, \mathrm{pd}, \mathrm{tu}$ \\
\hline 9. Hemostatics & $\mathrm{MeSH}$ & $\mathrm{ad}, \mathrm{ch}, \mathrm{pd}, \mathrm{tu}$ \\
\hline 10. Tissue Adhesive\$ & Free Text & $\mathrm{ab}, \mathrm{kw}, \mathrm{ti}$ \\
\hline 11. Fibrin Glue & Free Text & $\mathrm{ab}, \mathrm{kw}, \mathrm{ti}$ \\
\hline 12. Fibrin Sealant & Free Text & $\mathrm{ab}, \mathrm{kw}, \mathrm{ti}$ \\
\hline 13. Hemostasis & $\mathrm{MeSH}$ & de \\
\hline 14.8 or 9 or 10 or 11 or 12 or 13 & Combination & $\mathrm{N} / \mathrm{A}$ \\
\hline 15. Postoperative Haemorrhage & $\mathrm{MeSH}$ & $\mathrm{dt}, \mathrm{pc}, \mathrm{su}, \mathrm{th}$ \\
\hline 16. Postoperative Complications & $\mathrm{MeSH}$ & $\mathrm{dt}, \mathrm{pc}, \mathrm{su}, \mathrm{th}$ \\
\hline 17. Pain, Postoperative & $\mathrm{MeSH}$ & $\mathrm{dt}, \mathrm{pc}, \mathrm{su}, \mathrm{th}$ \\
\hline 18. Wound Healing & $\mathrm{MeSH}$ & de \\
\hline 19. Nasal Pack\$3 & Free Text & $\mathrm{ab}, \mathrm{kw}, \mathrm{ti}$ \\
\hline 20. 15 or 16 or 17 or 18 or 19 & Combination & $\mathrm{N} / \mathrm{A}$ \\
\hline 21.7 and 14 and 20 & Combination & $\mathrm{N} / \mathrm{A}$ \\
\hline
\end{tabular}

$\mathrm{su}=$ surgery, $\mathrm{pa}=$ pathology, $\mathrm{ab}=\mathrm{abstract}, \mathrm{kw}=$ keyword $, \mathrm{ti}=\mathrm{title}, \mathrm{ad}=$ administration $\&$ dosage, $\mathrm{ch}=$ chemistry, pd = pharmacology, tu = thera peutic use, de = drug effects, $d t=$ drug therapy, N/A = not applicable.
Appendix 4. Search Strategy for CINAHL (Ebsco host).

\begin{tabular}{|c|c|c|}
\hline Search Term & $\begin{array}{l}\text { Thesaurus } \\
\text { Term }\end{array}$ & $\begin{array}{l}\text { Subheading / } \\
\text { Search Field }\end{array}$ \\
\hline 1. Nasal Cavity & $\mathrm{MeSH}$ & su \\
\hline 2. Paranasal Sinuses & $\mathrm{MeSH}$ & su \\
\hline 3. Sinusitis & $\mathrm{MeSH}$ & su \\
\hline 4. Nose & $\mathrm{MeSH}$ & pa, su \\
\hline 5. Endoscopy & $\mathrm{MeSH}$ & All Subheadings \\
\hline 6. Sinus* W4 Surgery & Free Text & No Limits \\
\hline 7. 1 or 2 or 3 or 4 or 5 or 6 & Combination & $\mathrm{N} / \mathrm{A}$ \\
\hline 8. Fibrin Tissue Adhesives & $\mathrm{MeSH}$ & ad, tu \\
\hline 9. Hemostatics & $\mathrm{MeSH}$ & ad, tu \\
\hline 10. Tissue W4 Adhesive* & Free Text & No Limits \\
\hline 11. Fibrin W4 Glue & Free Text & No Limits \\
\hline 12. Fibrin W4 Seal\#nt & Free Text & No Limits \\
\hline 13. Hemostasis & $\mathrm{MeSH}$ & de \\
\hline 14.8 or 9 or 10 or 11 or 12 or 13 & Combination & $\mathrm{N} / \mathrm{A}$ \\
\hline 15. Postoperative Haemorrhage & $\mathrm{MeSH}$ & $\mathrm{dt}, \mathrm{pc}, \mathrm{su}, \mathrm{th}$ \\
\hline 16. Postoperative Complications & $\mathrm{MeSH}$ & $\mathrm{dt}, \mathrm{pc}, \mathrm{su}, \mathrm{th}$ \\
\hline 17. Pain, Postoperative & $\mathrm{MeSH}$ & $\mathrm{dt}, \mathrm{pc}, \mathrm{su}, \mathrm{th}$ \\
\hline 18. Wound Healing & $\mathrm{MeSH}$ & de \\
\hline 19. Nasal W4 Pack* & Free Text & No Limits \\
\hline 20.15 or 16 or 17 or 18 or 19 & Combination & $\mathrm{N} / \mathrm{A}$ \\
\hline 21.7 and 14 and 20 & Combination & N/A \\
\hline
\end{tabular}

$\mathrm{su}=$ surgery, $\mathrm{pa}=$ pathology, $\mathrm{ad}=$ administration $\&$ dosage, $\mathrm{tu}=$ thera peutic use, de = drug effects, $d t=$ drug therapy, $\mathrm{N} / \mathrm{A}=$ not applicable.

Appendix 5. Risk of Bias Table for Gleich et al. ${ }^{(24)}$

\begin{tabular}{|c|c|c|}
\hline Bias & $\begin{array}{l}\text { Author's } \\
\text { Judgement of Risk }\end{array}$ & Support for Judgement \\
\hline $\begin{array}{l}\text { Random sequence } \\
\text { generation (selec- } \\
\text { tion bias) }\end{array}$ & High risk & $\begin{array}{l}\text { Quote: "The side of application of fibrin tissue adhesive was randomly assigned before surgery... When } \\
\text { the patient's symptoms were more severe on one side or when, during the procedure, one side was } \\
\text { noted to have more severe disease, that side was selected for application of fibrin" (24). } \\
\text { Comment: The study does not clarify this, or state which method of randomisation was used, however } \\
\text { they do state that disease severity influenced how they organised patients into each group, which is a } \\
\text { poor way to conduct a randomised controlled trial. }\end{array}$ \\
\hline $\begin{array}{l}\text { Allocation } \\
\text { concealment } \\
\text { (selection bias) }\end{array}$ & High risk & $\begin{array}{l}\text { Although there was no information on the method of randomisation, the knowledge of the researchers } \\
\text { that they could allocate patients to a particular group based on disease severity meant the allocation } \\
\text { sequence was not concealed. }\end{array}$ \\
\hline $\begin{array}{l}\text { Blinding of } \\
\text { participants and } \\
\text { researchers (per- } \\
\text { formance bias) }\end{array}$ & High risk & $\begin{array}{l}\text { It was not stated if participants or researchers were kept blind to the intervention, however partici- } \\
\text { pants may have been able to tell if they were in the Gelfoam foam packing group due to the nasal ob- } \\
\text { struction. Furthermore, it would not have been possible to blind the surgeons as to which participants } \\
\text { were receiving Gelfoam and which received FTA. }\end{array}$ \\
\hline
\end{tabular}




\begin{tabular}{|c|c|c|}
\hline Bias & $\begin{array}{l}\text { Author's } \\
\text { Judgement of Risk }\end{array}$ & Support for Judgement \\
\hline $\begin{array}{l}\text { Blinding of out- } \\
\text { come assessment } \\
\text { (detection bias) }\end{array}$ & $\begin{array}{l}\text { Participant-assessed } \\
\text { outcomes: } \\
\text { Unclear risk } \\
\text { Clinician-assessed } \\
\text { outcomes: } \\
\text { High risk }\end{array}$ & $\begin{array}{l}\text { Quote: "The surgical procedures were performed by one surgeon (S. M. S.), and results of video-recor- } \\
\text { ded follow-up visits were evaluated by two additional surgeons (E. E. R. and L. L. G.)... Three surgeons } \\
\text { (S. M. S., E. E. R, and L. L. G.) evaluated all patients" (24). } \\
\text { Comment: Certain outcomes were assessed by the participants, and if they could feel which nasal } \\
\text { cavity had Gelfoam packing, this may have influenced their assessment. Furthermore, endoscopic } \\
\text { evaluation of outcomes was performed by the same surgeon that performed the operations rather } \\
\text { than independent researchers. }\end{array}$ \\
\hline $\begin{array}{l}\text { Incomplete } \\
\text { outcome data (at- } \\
\text { trition bias) }\end{array}$ & Unclear risk & $\begin{array}{l}\text { In this study there was not an intervention and control group, but an intervention and control nasal } \\
\text { cavity. This means every participant is acting as both the intervention and control group simultaneous- } \\
\text { ly; this prevents a disproportionate drop-out from one particular group. However, there was no data } \\
\text { available to explicitly say if patients had been lost to follow up. }\end{array}$ \\
\hline $\begin{array}{l}\text { Selective repor- } \\
\text { ting (reporting } \\
\text { bias) }\end{array}$ & Unclear risk & $\begin{array}{l}\text { The trial protocol was not available via a google search. As a result, the methods section was used to } \\
\text { compare intended outcomes with outcomes reported. No specific objectives were set out in this study, } \\
\text { and so it is not possible to tell if the reported outcomes matched what was initially intended to be } \\
\text { studied - furthermore, one of the intended outcome measures was not clearly reported (comfort). }\end{array}$ \\
\hline Other bias & Unclear risk & $\begin{array}{l}\text { Some patients may have received more FTA than others, and this could have impacted on the clinician } \\
\text { and participant-assessed outcomes assessed, especially of bleeding. }\end{array}$ \\
\hline
\end{tabular}

FTA $=$ Fibrin tissue adhesive

Appendix 6. Risk of Bias Table for Jung et al (25).

\begin{tabular}{|c|c|c|}
\hline Bias & $\begin{array}{l}\text { Author's } \\
\text { Judgement of Risk }\end{array}$ & Support for Judgement \\
\hline $\begin{array}{l}\text { Random sequence } \\
\text { generation (selec- } \\
\text { tion bias) }\end{array}$ & Low risk & $\begin{array}{l}\text { Quote: "1 nasal cavity randomly received aerosolised FS [fibrin sealant] and the opposite received } \\
\text { Nasopore packing material according to a computer-generated randomisation prepared by nursing } \\
\text { staff" (25). }\end{array}$ \\
\hline $\begin{array}{l}\text { Allocation } \\
\text { concealment } \\
\text { (selection bias) }\end{array}$ & Low risk & $\begin{array}{l}\text { The randomisation sequence was computer-generated and performed by nursing staff, meaning it } \\
\text { would not be possible for the surgeon to foresee the allocation sequence. }\end{array}$ \\
\hline $\begin{array}{l}\text { Blinding of } \\
\text { participants and } \\
\text { researchers (per- } \\
\text { formance bias) }\end{array}$ & High risk & $\begin{array}{l}\text { Quote: "The patients and observers were not informed of which side received which packing material" } \\
\text { (25). } \\
\text { Comment: Although participants were kept blind to the intervention, by the nature of the foam } \\
\text { packing, it would likely have been possible to tell which cavity had Nasopore and which had FTA. } \\
\text { Furthermore, it would not be possible to blind the providers (surgeons) to which intervention was used } \\
\text { in which nasal cavity. }\end{array}$ \\
\hline $\begin{array}{l}\text { Blinding of out- } \\
\text { come assessment } \\
\text { (detection bias) }\end{array}$ & $\begin{array}{l}\text { Participant-assessed } \\
\text { outcomes: } \\
\text { Unclear risk } \\
\text { Clinician-assessed } \\
\text { outcomes: } \\
\text { High risk }\end{array}$ & $\begin{array}{l}\text { Quote: "A physician other than the operating surgeon compared the subjective severity of symptoms... } \\
\text { postoperative endoscopic findings were assessed by outside observers using grading scales" (25). } \\
\text { Comment: Whilst third party independent clinicians collected the data, some outcomes were assessed } \\
\text { by the participants themselves. Due to the reasons stated above, if patients could feel which side had } \\
\text { the Nasopore packing, this may have influenced their assessment. The clinician-assessed outcomes, } \\
\text { however, would not have been affected and these were assessed by a physician other than the opera- } \\
\text { ting surgeon. }\end{array}$ \\
\hline $\begin{array}{l}\text { Incomplete } \\
\text { outcome data (at- } \\
\text { trition bias) }\end{array}$ & Low risk & $\begin{array}{l}\text { Quote: "43 patients were enrolled; and } 35 \text { patients underwent surgery and analysis" (25). } \\
\text { Comment: Despite } 8 \text { participants being enrolled but not undergoing surgery, in this study there was } \\
\text { not an intervention and control group, but an intervention and control nasal cavity. This means every } \\
\text { participant is acting as both the intervention and control group simultaneously; this prevents a dis- } \\
\text { proportionate drop-out from one particular group. Furthermore, the eight participants were excluded } \\
\text { before the intervention was administered, so these are not considered to have missing outcome data. }\end{array}$ \\
\hline $\begin{array}{l}\text { Selective repor- } \\
\text { ting (reporting } \\
\text { bias) }\end{array}$ & Low risk & $\begin{array}{l}\text { The trial protocol was not available via a google search. As a result, the methods section was used to } \\
\text { compare intended outcomes with outcomes reported. The objectives for the study were to compare } \\
\text { nasal packing against FTA use for haemostatic efficacy and wound healing. These outcomes were } \\
\text { reported equally for both groups alongside many other complications, such as adhesion rate and pain. } \\
\text { There is therefore no evidence of selective outcome reporting. }\end{array}$ \\
\hline Other bias & Unclear risk & $\begin{array}{l}\text { Some patients may have received more FTA than others, and this could have impacted on the clinician } \\
\text { and participant-assessed outcomes assessed, especially of bleeding. }\end{array}$ \\
\hline
\end{tabular}

FTA $=$ Fibrin tissue adhesive 


\begin{tabular}{|c|c|c|}
\hline Bias & $\begin{array}{l}\text { Author's } \\
\text { Judgement of Risk }\end{array}$ & Support for Judgement \\
\hline $\begin{array}{l}\text { Random sequence } \\
\text { generation (selec- } \\
\text { tion bias) }\end{array}$ & Unclear risk & $\begin{array}{l}\text { Quote: "Patients... were then randomised for further haemostatic technique by a sealed-envelope } \\
\text { method" (26). } \\
\text { Comment: This randomisation method can be considered as simple randomisation, which may not } \\
\text { be appropriate in a sample size of just } 64 \text {. Furthermore, it was not stated how the envelopes were } \\
\text { prepared or shuffled. }\end{array}$ \\
\hline $\begin{array}{l}\text { Allocation } \\
\text { concealment } \\
\text { (selection bias) }\end{array}$ & Unclear risk & $\begin{array}{l}\text { It was not stated who prepared or selected the envelopes, or if the envelopes were sequentially } \\
\text { numbered and opaque. It therefore cannot be assumed that the person selecting the envelopes was } \\
\text { unaware of the method used to generate the randomisation allocation sequence. }\end{array}$ \\
\hline $\begin{array}{l}\text { Blinding of } \\
\text { participants and } \\
\text { researchers (per- } \\
\text { formance bias) }\end{array}$ & High risk & $\begin{array}{l}\text { Quote: "The patients were randomly assigned by the sealed-envelope method, double blind, to one of } \\
\text { two treatment groups" (26). } \\
\text { Comment: The term 'double blind' was not qualified, and so it cannot be assumed who was subject } \\
\text { to blinding. Furthermore, participants may have been able to tell if they were in the Merocel foam } \\
\text { packing group due to the nasal obstruction, and it would not have been possible to blind the surgeons } \\
\text { as to which participants were receiving Merocel and which received FTA. }\end{array}$ \\
\hline $\begin{array}{l}\text { Blinding of out- } \\
\text { come assessment } \\
\text { (detection bias) }\end{array}$ & $\begin{array}{l}\text { Participant-assessed } \\
\text { outcomes: } \\
\text { Unclear risk } \\
\text { Clinician-assessed } \\
\text { outcomes: } \\
\text { High risk }\end{array}$ & $\begin{array}{l}\text { Quote: "The observers were the authors and other physicians from the otolaryngology department, } \\
\text { blind to the original intervention"(26). } \\
\text { Comment: Whilst third party clinicians collected the data, some outcomes were assessed by the parti- } \\
\text { cipants themselves. Due to the reasons stated above, if participants could feel if they had the Merocel } \\
\text { packing, this may have influenced their outcome assessment as they were not blind to the interventi- } \\
\text { on. The clinician-assessed outcomes, however, would not have been affected, and these were assessed } \\
\text { by observers who were blind to intervention. }\end{array}$ \\
\hline $\begin{array}{l}\text { Incomplete } \\
\text { outcome data (at- } \\
\text { trition bias) }\end{array}$ & Low risk & $\begin{array}{l}\text { Quote: "No patients were lost to follow up" (26). } \\
\text { Comment: all patients that were enrolled and randomised completed the study. }\end{array}$ \\
\hline $\begin{array}{l}\text { Selective repor- } \\
\text { ting (reporting } \\
\text { bias) }\end{array}$ & High risk & $\begin{array}{l}\text { The trial protocol was not available via a google search. As a result, the methods section was used } \\
\text { to compare intended outcomes with outcomes reported. The aim of the study was to compare the } \\
\text { haemostatic properties of fibrin sealant with nasal packing. Haemostatic efficacy was assessed equally } \\
\text { between the groups, however only additional clinician-assessed outcomes (adhesions, atrophic chan- } \\
\text { ges) were evaluated in the FTA group and additional participant-assessed outcomes (pain, obstruction) } \\
\text { were evaluated in the nasal pack group. This again raises the suspicion of selective reporting, as there } \\
\text { was evidence of all participant-assessed symptoms in the nasal-packing group, and no evidence of any } \\
\text { clinician-assessed outcomes in the FTA }\end{array}$ \\
\hline Other bias & Unclear risk & $\begin{array}{l}\text { Some patients may have received more FTA than others, and this could have impacted on the clinician } \\
\text { and participant-assessed outcomes assessed, especially of bleeding. }\end{array}$ \\
\hline
\end{tabular}

FTA $=$ Fibrin tissue adhesive

Appendix 8. Risk of Bias Table for Yu et al. ${ }^{(12)}$.

\begin{tabular}{|c|c|c|}
\hline Bias & $\begin{array}{l}\text { Author's Judge- } \\
\text { ment of Risk }\end{array}$ & Support for Judgement \\
\hline $\begin{array}{l}\text { Random sequence } \\
\text { generation (selec- } \\
\text { tion bias) }\end{array}$ & Low risk & $\begin{array}{l}\text { Quote: "The order of packing was randomized according to a computer-generated randomization } \\
\text { that was prepared by the nursing staff when the surgery was completed but before the packing was } \\
\text { inserted"(12). } \\
\text { Comment: Computer-generated sequence generation can be considered low risk. }\end{array}$ \\
\hline $\begin{array}{l}\text { Allocation } \\
\text { concealment } \\
\text { (selection bias) }\end{array}$ & Low risk & $\begin{array}{l}\text { The randomisation sequence was computer-generated and performed by nursing staff, meaning it } \\
\text { would not be possible for the surgeon to foresee the allocation sequence. }\end{array}$ \\
\hline $\begin{array}{l}\text { Blinding of } \\
\text { participants and } \\
\text { researchers (per- } \\
\text { formance bias) }\end{array}$ & High risk & $\begin{array}{l}\text { It was not stated if participants or researchers were kept blind to the intervention, however partici- } \\
\text { pants may have been able to tell if they were in the Merocel foam packing group due to the nasal ob- } \\
\text { struction. Furthermore, it would not have been possible to blind the surgeons as to which participants } \\
\text { were receiving Merocel and which received FTA. }\end{array}$ \\
\hline $\begin{array}{l}\text { Blinding of out- } \\
\text { come assessment } \\
\text { (detection bias) }\end{array}$ & $\begin{array}{l}\text { Participant-assessed } \\
\text { outcomes: } \\
\text { Unclear risk } \\
\text { Clinician-assessed } \\
\text { outcomes: } \\
\text { High risk }\end{array}$ & $\begin{array}{l}\text { It was not stated who collected the data and if they were blind to intervention. Certain outcomes were } \\
\text { assessed by the participants themselves; due to the reasons stated above, if patients could feel if they } \\
\text { had the Merocel packing, this may have influenced their assessment as they were not blind to the } \\
\text { intervention. Clinician-assessed outcomes would not have been affected by this, but by not stating if } \\
\text { the observers were blind, we cannot assume they were. }\end{array}$ \\
\hline
\end{tabular}




\begin{tabular}{|c|c|c|}
\hline Bias & $\begin{array}{l}\text { Author's Judge- } \\
\text { ment of Risk }\end{array}$ & Support for Judgement \\
\hline $\begin{array}{l}\text { Incomplete } \\
\text { outcome data (at- } \\
\text { trition bias) }\end{array}$ & Low risk & $\begin{array}{l}\text { Quote: "50 patients were enrolled, and } 41 \text { patients underwent surgery and analysis. A total of nine } \\
\text { patients who were enrolled did not undergo surgery and were thus excluded" (12). } \\
\text { Comment: Despite nine participants being enrolled but not undergoing surgery, in this study there } \\
\text { was not an intervention and control group, but an intervention and control nasal cavity. This means } \\
\text { every participant is acting as both the intervention and control group simultaneously; this prevents a } \\
\text { disproportionate drop-out from one particular group. Furthermore, the nine participants were exclu- } \\
\text { ded before the intervention was administered, so these are not considered to have missing outcome } \\
\text { data. }\end{array}$ \\
\hline $\begin{array}{l}\text { Selective repor- } \\
\text { ting (reporting } \\
\text { bias) }\end{array}$ & Low risk & $\begin{array}{l}\text { The trial protocol was not available via a google search. As a result, the methods section was used to } \\
\text { compare intended outcomes with outcomes reported. The objectives of this study were to "determine } \\
\text { the effect of aerosolised [fibrin sealant] on haemostasis and wound healing after [functional endosco- } \\
\text { pic sinus surgery] compared with a standard non-absorbable packing (Merocel) requiring removal. Our } \\
\text { secondary objective was to examine the subjective severity of symptoms after [functional endoscopic } \\
\text { sinus surgery]" (12). These outcomes were reported equally between the FTA and packing sides, along- } \\
\text { side additional outcome measures. There is therefore no evidence to suggest that some outcomes } \\
\text { were deliberately not reported. }\end{array}$ \\
\hline Other bias & Unclear risk & $\begin{array}{l}\text { Some patients may have received more FTA than others, and this could have impacted on the clinician } \\
\text { and participant-assessed outcomes assessed, especially of bleeding. }\end{array}$ \\
\hline
\end{tabular}

FTA = Fibrin tissue adhesive 